\title{
Development of Learning Tools and Disaster Mitigation Boxes Student Oriented Learning Model in Raising Student Awareness
}

\author{
Syahrial Ayub1*, Kosim¹, I Wayan Gunada1, Muh. Mahrus ${ }^{1}$ \\ ${ }^{1}$ Study Program of Physics Education, University of Mataram, Mataram, Indonesia.
}

DOI: $10.29303 /$ jossed.v2i1.718

\section{Article Info}

Received : February 28th, 2021

Revised : April 20th, 2021

Accepted: April 24th, 2021

\begin{abstract}
This study aims to develop disaster mitigation learning tools in raising awareness of students in elementary schools. Research design using 4D models, namely define, design, develop, and disseminate. Disaster mitigation learning tools developed are disaster mitigation boxes, learning implementation plans, student worksheets. The data was collected with questionnaires and tests measuring students' disaster awareness. The testing phase is the stage to find out the effect of the use of disaster mitigation learning tools on increasing student awareness. Student awareness raising is determined based on N-Gain and paired t-test. The results showed the learning tools and disaster mitigation boxes developed were declared valid and reliable, worthy of use in terms of content and construction and influential in raising disaster awareness of learners.
\end{abstract}

Keywords: Disaster mitigation learning tools; Student oriented learning model; Student disaster awareness.

Citation: $\quad$ Ayub, S., Kosim, K., Gunada, I., \& Mahrus, M. (2021). Pengembangan Perangkat Pembelajaran dan Kotak Mitigasi Bencana Model Student Oriented Learning dalam Meningkatkan Kesadaran Peserta Didik. Journal of Science and Science Education, 2(1), 22-28. doi:https://doi.org/10.29303/jossed.v2i1.718

\section{Introduction}

Disaster is an event or series of events that threaten and disrupt people's lives and livelihoods caused by natural and non-natural factors resulting in fatalities, environmental damage, property losses, and psychological impacts (Diposaptono, 2005). Disasters can happen at any time and no human being can know the time and place (Wibowo \& Sudarsono, 2017). Disasters can occur while sleeping, working, worship, playing, and even while studying at school (Daima \&Mikdar, 2020). Teachers, students and other school devices are people affected in the event of a disaster during the learning process. Disaster preparedness is indispensable for them to reduce the impact of the disaster risk. According to law no. 24 of 2007 on disasters, preparedness is a series of activities carried out to anticipate disasters through appropriate and effective measures. Preparedness in the form of actions that enable governments, organizations, communities, communities and individuals to be able to respond to disaster situations quickly and appropriately (DAPS, 2006).

The school as one of the gathering places of many students is expected to have disaster preparedness programs so that disaster awareness arises for students and other school devices (Ramadhani et al., 2020). Instilling disaster awareness in learners is a process (Ayub, 2019). Disaster awareness is impossible to just appear without proper activities to instill it. The school is one of the places that can be used to instill disaster awareness to students. Learning activities that are done should use props, so as to make students happy to follow the learning. In accordance with the above opinion the learning process using props is believed to be better. Learning by using science kits provides motivation and improves the ability of the student process (Ayub, 2019). The above 
problems should be a means of introspection for teachers. Instropeksi to find the right models, methods and media used in learning (Djamarah, 2005).

One of the efforts to make learning that is able to instill disaster awareness in students is to create a learning medium in the form of a disaster mitigation box. Disaster knowledge is very necessary to be given to students (Suprapto, 2002). Learning tools are the right place to accommodate the ideas, ideas and thoughts above. Disaster mitigation learning tools developed include 5 aspects of disaster that are expected to be able to instill disaster awareness in students. Five aspects of disaster will be given gradually and systematically to students. These five aspects are disaster knowledge (PK), signs of disaster (TB), impact of risk and efforts to reduce (DR), preparedness $(\mathrm{KN})$, and procedures, first aid equipment on victims (AP).

The development of learning tools covering 5 aspects is expected to cause disaster awareness for students. Disaster awareness that arises in students will increase the knowledge, skills, and attitudes of learners in dealing with when disasters occur. According to law no. 24 of 2007, disaster mitigation is a series of efforts to reduce the risk of disasters, both through physical development and awareness and improved ability to deal with disasters.

Disaster mitigation activities include the introduction and monitoring of disaster risk, giving rise to a culture of disaster awareness, the application of physical and non-physical efforts in disaster management arrangements, monitoring the use of technology, monitoring the implementation of spatial and environmental and other. These disaster mitigation activities will be applied to disaster mitigation learning in schools. Observations and interviews with teachers at SD Negeri 6 Mataram found that disaster mitigation learning tools have not been developed at all. This is because until now there is no disaster mitigation curriculum in schools.

Disaster mitigation learning in schools is very necessary in order for students' disaster awareness to increase. Student oriented learning model is a model of discovery (discovery learning) and based on problems. Students in student oriented learning have a major and large role. In this study, students are expected to be able to find problems, submit hypotheses, conduct activities to answer problems and find conclusions and apply them in life. In this study, disaster mitigation learning tools were designed with student oriented learning model in improving students' problem solving skills. The problem is how the characteristics of learning tools developed with student oriented learning are used to improve the problem solving skills of students and learning devices.

Disaster problem solving capability is a process of using the ability to answer a disaster problem. Indicators of problem solving capabilities are (1) understanding problems, (2) planning problem solving, (3) implementing problem solving, (4) re-examining solutions (Sujarwanto et al., 2014). So student oriented learning is learning that is activity-oriented centered on students in finding problems, planning problem solving, carrying out problem solving, finding conclusions and communicating problem solving found (Subrata, 2001). Teachers are only facilitators in this learning. The teacher's explanation is only when needed, for example at the end of this activity the learner formulates a conclusion that means the problems that arise at the beginning of the learning should be answered, but the students still ask a lot to come here and the class is a little noisy. This is a sign that students still do not understand the concept that we teach so it needs a teacher explanation. More details of problem solving learning structure can be seen in Table 1.

Table 1. Problem solving learning structure

\begin{tabular}{lll}
\hline No & Teaching Steps & Teaching Step Objectives \\
\hline 1. & Motivation & Arouse students' interest and curiosity in the subject matter to be taught \\
2. & Problem description & Formulating a scientific question \\
3. & Opinion Drafting & Formulation of hypotheses \\
4. & Planning and Construction & Preparation of the experimental equipment to be used \\
5. & Experiment & The embodiment of a natural reaction \\
6. & Conclusion & Conclusion of a troubleshooting procedure \\
7. & Abstraction & Legitimate scientific results \\
8. & Consolidation of knowledge & Comprehensive knowledge of natural symptoms and integration of \\
& through applications and practices & educational outcomes \\
\hline
\end{tabular}

Klinger, (1997)

The problem is how the characteristics of disaster mitigation learning tools developed with student oriented learning are used to improve the problem solving skills of students and learning devices. Problem solving capability is a process of using the ability to answer a problem. Student oriented learning is learning 
that is activity-oriented centered on students in finding problems, planning problem solving, carrying out problem solving, finding conclusions and communicating problem solving found (Ibrahim, 2000). This method has several advantages, including: 1) the development of self-reliance and independent activities of learners; 2) stimulation of the ability to plan, organize and carry out activities; 3 ) the development of responsibility for an activity, and 4) the introduction of working and thinking methods in the field of research. Discovery learning model positively affects students' learning outcomes (Sahidu et al., 2017).

Problem Based Learning model is problem solving related to learning materials, not how teachers deliver learning materials (Sugiyono, 2013). Problembased learning models with experimental methods provide an authentic experience that encourages learners to learn actively (Lidiana et al., 2018). This is what encourages researchers to develop learning tools with student oriented learning models applied to disaster mitigation to increase student awareness.

\section{Method}

This research uses a type of research and development with $4 \mathrm{D}$ research design models namely Define, Design, Develop, and Desseminate. At the Define stage, analysis of disaster mitigation materials, analysis of students' abilities, analysis of tasks to be given, concept analysis and analysis of learning objectives of disaster mitigation. The Design stage is carried out the design of learning devices. In the Develop stage, product manufacturing, product expert validation, product revision, testing tools evaluate disaster mitigation capabilities for the awareness of learners, while at the desseminate stage is only done in limited students, namely in class V SD Negeri 6 Mataram. Research data in the form of input data and suggestions from expert validators (qualitative data) and validation data of learning devices and trials of evaluation tools. Data collection tools in the form of expert validation questionnaires and disaster mitigation capabilities. Data analysis using validity test validator using average validator value:

$N A=\frac{V_{1}+V_{2}+V_{8}+V_{4}}{4}$

the results of the average value of validators are consulted in Table 2, the validity assessment criteria (Ratumanan \& Laurens, 2011), i.e.

Table 2. Validity Assessment Criteria

\begin{tabular}{lll}
\hline Average & Category & Decision \\
\hline $1,00-1,75$ & Not Valid & Total revision \\
\hline
\end{tabular}

\begin{tabular}{lll}
\hline $1,76-2,50$ & Fairly valid & Revision \\
$2,51-3,25$ & Valid & Revisions as suggested \\
$3,26-4,00$ & Very valid & No revision required \\
\hline
\end{tabular}

Expert validation data from disaster mitigation capability evaluation tool trials, analyzed with Percentage Agreement (Borich, 1994).

Percentage Agreement $=\left(1-\frac{A-B}{A+B}\right) 100 \%$

By criteria, reliabel $\geq 75 \%$, Percentage Agreement is the percentage of agreement between the assessor which is a percentage of the suitability of value between the first and second assessors. Where $\mathrm{A}$ is a larger assessor score and B a smaller appraiser score. The improved quality of disaster mitigation is seen from the N-Gain value. According to Halpern, (1998), the N-Gain value is calculated by the:

$<g>=\frac{s_{\text {post }}-s_{\text {pre }}}{s_{\text {maks }}-s_{\text {pre }}}$

where, $\langle g\rangle$ is the N-Gain score, $S_{\text {post }}$ is posttest score $S_{\text {pre }}$ is pretest score, and $S_{\text {maks }}$ maximum score.

Table 3. N-Gain Score Criteria

\begin{tabular}{lll}
\hline No & $\begin{array}{l}\text { N-Gain Score } \\
\text { Classification }\end{array}$ & Category \\
\hline 1 & $0,7<\langle g\rangle \leq 1$ & High \\
2 & $0,3<\langle g\rangle \leq 0,7$ & Medium \\
3 & $\langle g\rangle \leq 0,3$ & Low \\
\hline
\end{tabular}

The analysis of pretest and posttest data is statistically analyzed using pair t-test at the level of significance ( $\mathrm{p}$ value) of 0.05 . Previously tested the normality of the sample. Homogeneity tests are conducted to convince hypothetical tests to be conducted. The research hypothesis tested, namely $\mathrm{Ha}$ (student oriented learning model disaster mitigation learning tool is effective against increasing student awareness), and Ho (student oriented learning model disaster mitigation learning device is ineffective to increase student awareness).

\section{Result and Discussion}

Research products in the form of disaster mitigation boxes, learning implementation plans and student worksheets such as in figure 1 and figure 2 . 


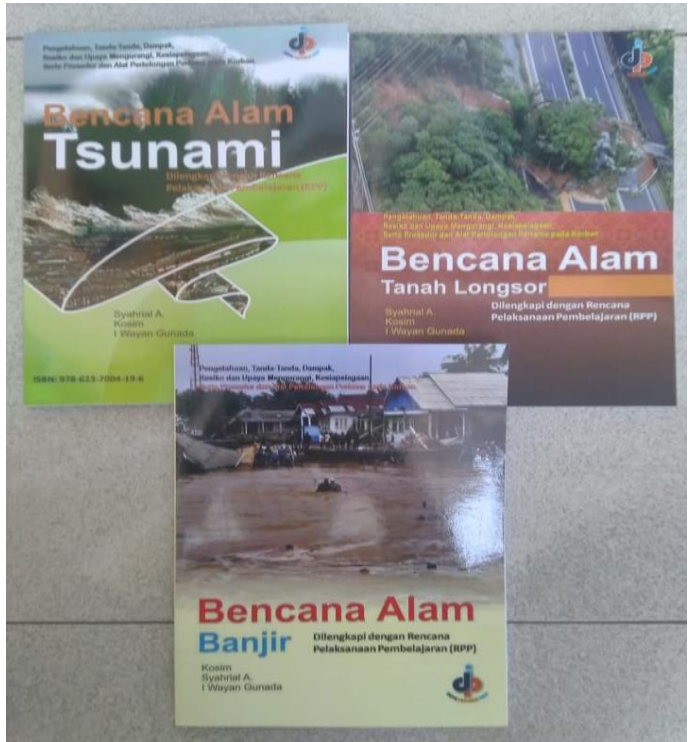

Figure 1. Natural disaster book products containing Learning Program Plan and Student Worksheet (SW)

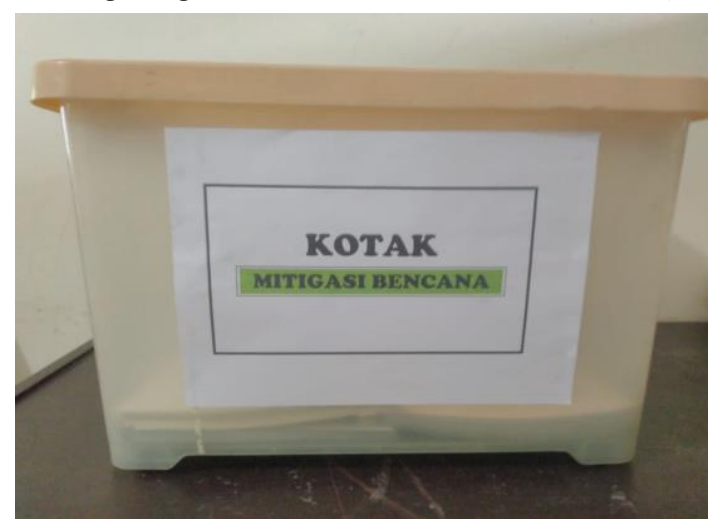

Figure 2. Disaster mitigation box products
Validation results from disaster mitigation experts and expert lecturers using a scale assessment of 4 , against disaster mitigation box props based on image quality, content quality and objectives, learning quality, obtained an average score of 3.56 with a category is very feasible to use. The criteria are very feasible to be used also obtained for Learning Program Plan and Student Worksheet (SW) which get scores of 3.75 and 3.82 , respectively. So that overall can be stated box props and disaster mitigation learning devices are very feasible to be used for disaster learning (according to the criteria of assessment validity Table-2).

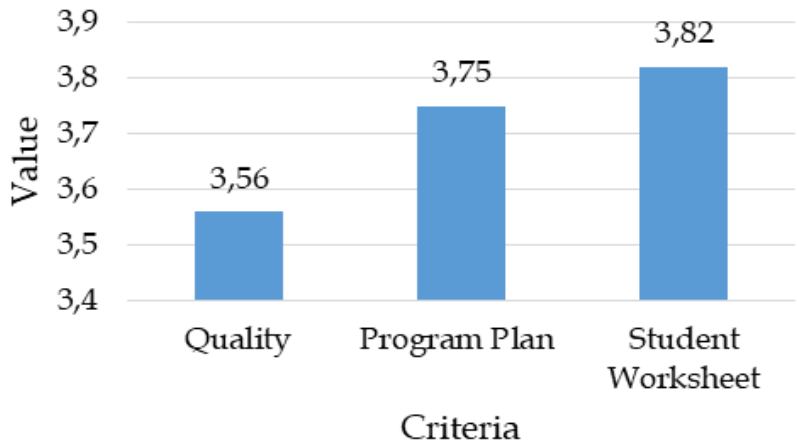

Figure 3. Validation results of learning tools and disaster mitigation boxes

The results of the analysis of percentage agreement (PA) values from validators to student disaster mitigation learning tools can be seen in Table 4 .

Table 4. Reliability Analysis of Expert Validators

\begin{tabular}{|c|c|c|c|c|c|c|c|c|}
\hline \multirow{2}{*}{ Products } & \multicolumn{6}{|c|}{ PA Value of Validator (\%) } & \multirow{2}{*}{$\mathrm{V}$} & \multirow{2}{*}{ Description } \\
\hline & $\mathrm{V}_{12}$ & $\mathrm{~V}_{13}$ & $\mathrm{~V}_{14}$ & $\mathrm{~V}_{23}$ & $\mathrm{~V}_{24}$ & $\mathrm{~V}_{34}$ & & \\
\hline Box & 98 & 93 & 100 & 90 & 95 & 100 & 96 & Reliabel \\
\hline Learning Program Plan & 100 & 98 & 93 & 98 & 96 & 91 & 96 & Reliabel \\
\hline SW & 94 & 90 & 98 & 88 & 100 & 100 & 94 & Reliabel \\
\hline Assay & 96 & 98 & 94 & 99 & 97 & 100 & 97 & Reliabel \\
\hline
\end{tabular}

Disaster awareness in this study, including disaster knowledge (PK), disaster signs (TB), risk impacts and efforts to reduce (DR), preparedness $(\mathrm{KN})$, and procedures, first aid equipment on victims (AP) (Ayub, 2019). The pretest includes the 5 disaster awareness knowledge and skills outlined above. Problems that meet the requirements are used to measure the learner's initial ability. After the pretest, then conducted disaster mitigation learning as many as 5 meetings. The five meetings were 1) PK, 2) TB, 3) DR, 4) KS, and 5) AP. Posttest was conducted at the sixth meeting using improved pretest questions. Pretest and posttest results shown in Figure 4.

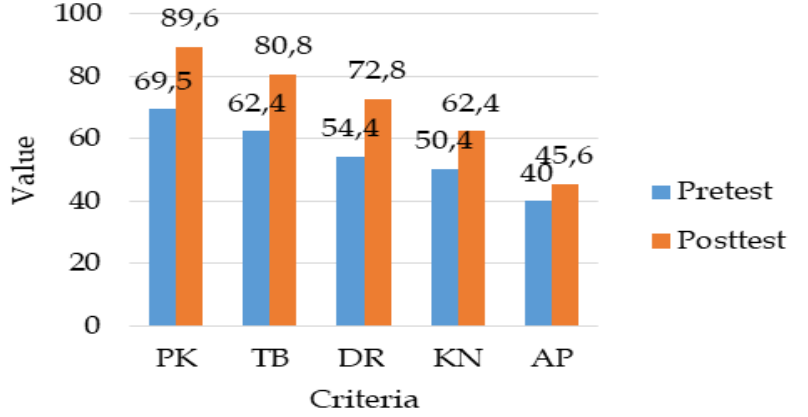

Figure 4. Pretest graph and Posttest Results of Learning disaster mitigation and Aspects of Bencan Awarenessa 
Pretest and posttest data used to calculate N-Gain in Table 5.

Table 5. Data Gain Score of each Aspect of Disaster Awareness

\begin{tabular}{lllll}
\hline AKB & Initial Test & Final Test & $\begin{array}{l}\text { Gain } \\
\text { Score }\end{array}$ & Criteria \\
\hline PK & 69,60 & 89,60 & 0,89 & High \\
TB & 62,40 & 80,80 & 0,62 & Medium \\
DR & 54,40 & 72,80 & 0,49 & Medium \\
KN & 50,40 & 62,40 & 0,29 & Low \\
AP & 40,00 & 45,60 & 0,11 & Low \\
\hline
\end{tabular}

Table 5 is an indicator that learning tools and disaster mitigation boxes can be used for disaster learning in primary schools. Gain Score of disaster awareness learning results shown in Figure 5.

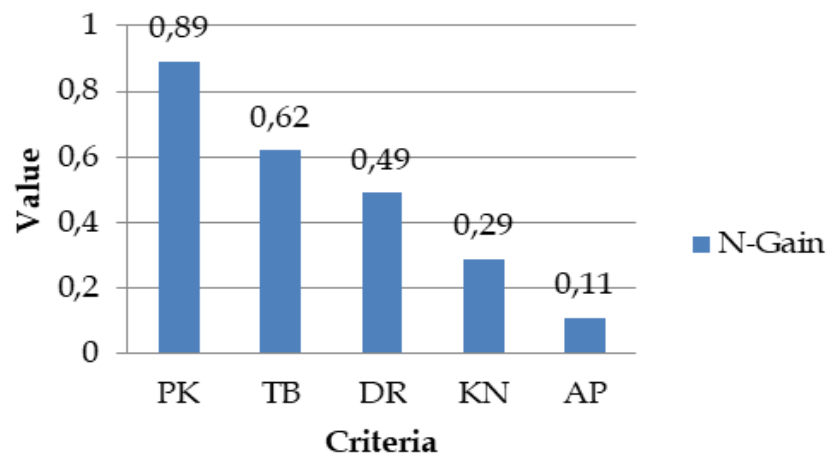

Figure 5. Graph of Gain Score of Disaster Awareness Learning Results

The response of students to learning with disaster mitigation box props was $83.5 \%$ of students expressed delight, $73.6 \%$ of students expressed easy understanding and $81.43 \%$ expressed useful.

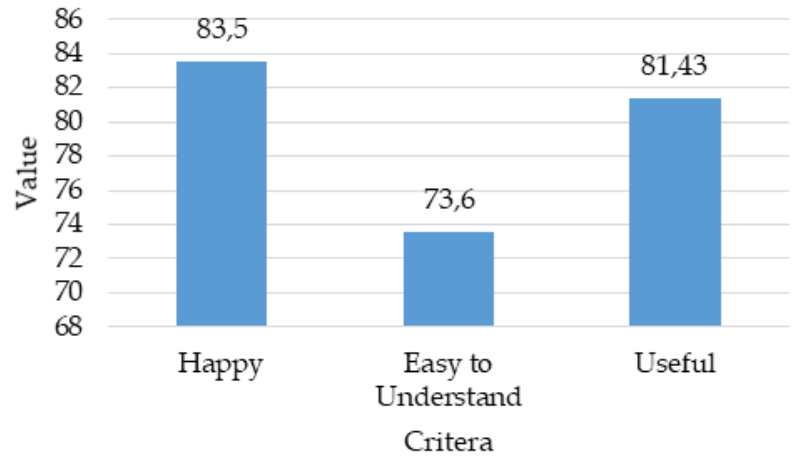

Figure 6. Student Response to Learning with Disaster Mitigation Box

Assessment of the learning process conducted by observers obtained results, aspect 1) learning preparation obtained a score of 3.85 with excellent criteria, aspect 2) the implementation of learning obtained a score of 3.91 with excellent criteria, and aspect 3) the activities of learners in learning obtained a score of 3.89 with very good criteria. Overall according to observers disaster learning goes very well.

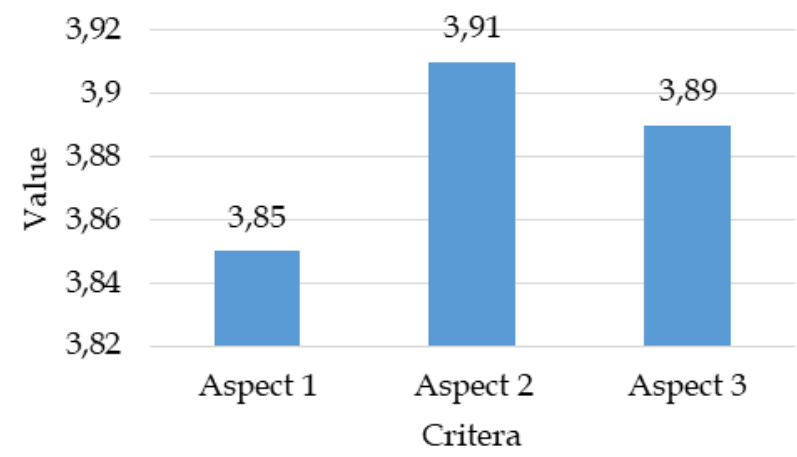

Figure 7. Observer's Assessment of the Learning Process

Based on the data of disaster awareness learning outcomes and improved scores of learning outcomes illustrated that learning with disaster mitigation box props affects the disaster awareness of learners.

Normality tests, t-tests and homogeneity tests are conducted using SPSS 23.0. The paired t-test used is a different parametric test on two paired data. In accordance with this understanding, this test is intended for different tests or comparative tests on average two pairs of samples. The two samples in question are the same sample but have two data. Paired t-test is part of parametric statistics, therefore as the rules of parametric statistics research data must be distributed normally. Normal distributed means that pretest and posttest scores have the appropriate proportions between high, medium, and low scores. The score is not concentrated on high, low, or moderate scores only. Kolmogorov-Smirnov normality test can be seen in Table 6.

Table 6. Pretest and posttest normality test results

\begin{tabular}{ll}
\hline Criteria & Unstandardized Residual \\
\hline Kolmogorov-Smirnov Z & 0.739 \\
Asymp. Sig. (2-tailed) & 0.646 \\
\hline
\end{tabular}

The Kolmogorov-Smirnov normality test is part of a classic assumption test that aims to find out if the residual value is normally distributed or not. A good regression model is to have residuals that are normally distributed. The hypothesis formulation on the normality test is, Ho; normally distributed residual values, and $\mathrm{Hi}$; residual value is not nomal distributed. The basis for conclusion, if the significance value (sig.) $>0.05$ then Ho is accepted, Hi is rejected meaning the residual value is normally distributed. If significance (sig.) $<0.05$ then Hi is accepted, Ho is rejected meaning the residual value is not normally distributed. 
Kolmogorov-Smirnov's normality test results showed a value of 0.649 greater than 0.05 , meaning that the pretest and posttest in this study were normally distributed. After the normality test is conducted, a paired $t$-test is conducted to determine the effectiveness of the use of learning devices and disaster mitigation boxes. The results of the paired t-test can be seen in Table 7.

Table 7. Paired t-test pretest and posttest test results

\begin{tabular}{llll}
\hline Criteria & $\mathrm{t}$ & $\mathrm{df}$ & Sig. (2-tailed) \\
\hline pretest - posttest & -11.299 & 24 & 0.000
\end{tabular}

The basis of decision making test results paired $t$ test is; 1 ) if the value is Sig. (2-tailed) $<0.05$, then there is a significant difference between pretest and posttest; 2 ) if the Sig. (2-tailed) value $>0.05$, then there is no significant difference between pretest and posttest. Table 6 showing Sig values. (2-tailed) $0.000<0.05$, it can be concluded that there is a significant difference between pretest and posttest in learning using disaster mitigation devices and boxes at SD Negeri 6 Mataram. This indicates the effectiveness of the use of learning devices and disaster mitigation boxes to the awareness of learners.

The learning structure of disaster mitigation model of student oriented learning consists of 3 main stages of learning, namely initial activities, core

Table 8. learning structure of student oriented learning

\begin{tabular}{|c|c|c|}
\hline Main Stage & Learning Stage & Alternative Activities \\
\hline Early activities & - Introduction & $\begin{array}{l}\text { - demo tools brought by teachers } \\
\text { - video playback } \\
\text { - storytelling/events } \\
\text { - sing } \\
\text { - review } \\
\text { - observe the environment } \\
\text { - phenomenon } \\
\text { - aperception }\end{array}$ \\
\hline Core activities & $\begin{array}{l}\text { - Problem formulation } \\
\text { - Activities to answer problems }\end{array}$ & $\begin{array}{l}\text { - formulate questions and be written } \\
\text { - practice/experimentation } \\
\text { - game/simulation } \\
\text { - grouping } \\
\text { - check disaster mitigation tools } \\
\text { - check technical tools } \\
\text { - first aid to the victim }\end{array}$ \\
\hline & $\begin{array}{l}\text { - Observation } \\
\text { - Troubleshooting }\end{array}$ & $\begin{array}{l}\text { - make as many observations as possible } \\
\text { - student explanation (guess-guess-discussion) } \\
\text { - the foundation of thought }\end{array}$ \\
\hline & - Conclusion & - learners formulate conclusions \\
\hline $\begin{array}{l}\text { Stabilization } \\
\text { Activities }\end{array}$ & $\begin{array}{l}\text { - Teacher Explanation (when } \\
\text { required) }\end{array}$ & $\begin{array}{l}\text { - application } \\
\text { - answer questions } \\
\text { - create a summary } \\
\text { - homework }\end{array}$ \\
\hline
\end{tabular}

(developed from SEQIP, 2000)

This structure is applied to the development of learning implementation plans and student worksheets as well activities and stabilization activities. Each of the main stages has a purpose. The initial activity is intended to motivate students and make students interested and long for learning. If this has been achieved, it is easy for teachers to achieve their learning goals. The core activities are characterized by problems raised by students through teacher guidance. The teacher formulates and notes on the board. Problems should not be answered directly by the teacher. Teachers are expected to only ask for temporary answers (hypotheses) from students. The hypothesis presented by the students should not be blamed or justified by the teacher, just accommodated because it is expected that later at the end of the core activities will be answered by themselves from the activities carried out. Furthermore, the teacher accompanies the students to do activities in answering the problems that have been formulated. Through activities, observations, discussions and based on the basis of appropriate theory, it is expected that with the facilitation of teachers, students are able to get their own conclusions. Finally, the teacher explains the application of concepts that have been found in life. We recommend that examples of application exist in the environment of the learners taught. as disaster mitigation boxes. The disaster mitigation box contains; 1) book of natural disasters earthquakes, 
tsunamis, landslides and floods containing 5 aspects of disasters, Learning Program Plan and Student Worksheet $(\mathrm{SW})$; 2) aspects of disaster awareness containing disaster knowledge (PK), disaster signs (TB), impact of risks and efforts to reduce (DR), preparedness $(\mathrm{KN})$, and procedures and tools of first aid to victims (AP).

\section{Conclusion}

Learning tools and disaster mitigation boxes developed are declared valid and reliable, worthy of use in terms of content and construction and influential in raising awareness of disaster learners.

\section{Acknowledgements}

Alhamdulilah, thank you to the Director General of Higher Education through LPPM University of Mataram who has provided research funds for the decentralization of universities so that the implementation of this research. Thank you to SD Negeri 6 Mataram which is a pilot research project that has provided facilities and opportunities to carry out research.

\section{References}

Ayub, S. (2019). Model Pembelajaran Kesiapsiagaan Gempabumi di Sekolah Dasar. Jurnal Orbita Universitas Muhammadyah Mataram, 5(2), 65-72. doi: https://doi.org/10.31764/orbita.v5i2.1187 [Indonesian]

Borich, G.D., (1994). Obsevation Skill for Effective Teaching. New York: Macmillan Publishing Company.

Daima, U.Z., \& Mikdar, Z. (2020). Dampak Pandemi Covid-19 terhadap Perilaku Belajar, Interaksi Sosial dan Kesehatan bagi Mahasiswa FKIP Universitas Palangka Raya. Journal of Sport Science and Education, 5(2), 124-138. Retrieved from: http://journal.unesa.ac.id/index.php/jossae/inde xhttp://dx.doi.org/10.26740/jossae.v5n2.p124-138 [Indonesian]

DAPS. (2006). Materi Pelatihan Bencana (Gempabumi, Banjir, Tanah Longsor, Tsunami). Jakarta: Depdiknas-GTZ SEQIP. [Indonesian]

Diposaptono, S. (2005). Tsunami Mitigation Technology. Jakarta: Republic of Indonesia Maritime and Fisheries Agency Tsunami Mitigation Training Material. [Indonesian]

Djamarah. (2005). Teachers and Students in Educative Interaction, A Psychological Theoretical Approach. Jakarta: Rineka Cipta.
Halpern, D.F. (1998). Teaching critical thinking for transfer across domains. American Psychologist, 53(4), h.449-455. 2018.

Ibrahim, M. (2000). Problem Based Learning. Surabaya: University Press

Klinger, W. (1997). Survey of Teaching Methods in Natural Sciences. Erziehungswiss. Fakultat der Universtat: Erlangen-Nurnbe.

Lidiana, H., Gunawan, G., \& Taufik, M. (2018). Pengaruh Model Discovery Learning Berbantuan Media PhET Terhadap Hasil Belajar Fisika Peserta Didik Kelas XI SMAN 1 Kediri Tahun Ajaran 2017/2018. Jurnal Pendidikan Fisika dan Teknologi, 4(1), 33-39. doi: http://dx.doi.org/10.29303/jpft.v4i1.519 [Indonesian]

Ramadhani, R.M., Gustaman, F.A.I., Kodar, M.S., \& Widanaha, I.K. (2020). Implementasi Program Sekolah Aman Bencana Di Sekolah Menengah Kejuruan Negeri 4 Balikpapan Kalimantan Timur. Jurnal Pendidikan Ilmu Pengetahuan Sosial Indonesia, 7(2), 162-176. [Indonesian]

Ratumanan, G.T., \& Laurens, T. (2011). Evaluasi Hasil Belajar pada Tingkat Satuan Pendidikan. Surabaya : UNESA University Press. [Indonesian]

Sahidu, H., Gunawan, Indriaturrahmi, \& Astutik, F. (2017). Desain Sistem E-Assessment pada Pembelajaran Fisika di LPTK. Jurnal Pendidikan Fisika dan Teknologi, 3(2), 65-74. doi: http://dx.doi.org/10.29303/ipft.v3i2.422 [Indonesian]

Subrata. (2001). Efforts to Improve the Quality of Learning Outcomes of Elementary Students through Science Learning with Process Skills. Singaraja: LPPM STKIP Singaraja.

Sugiyono. (2013). Qualitative Quantitative Research Methods and $R \mathcal{E} D$. Bandung: Alfabeta.

Sujarwanto, E., Hidayat, A., Wartono, W. (2014). Kemampuan Pemecahan Masalah Fisika pada Modeling Instruction pada Siswa Kelas XI. Jurnal Pendidikan IPA Indonesia. 20(1), 65-75. Retrieved from https://doi.org/10.15294/jpii.v3i1.2903 [Indonesian]

Suprapto, S. (2002). Flood Disaster, Material for Disaster Power Training. Yogyakarta : PSBA UGM.

Wibowo, S., \& Sudarsono, A. (2017). Pemahaman Menejemen Bencana Siswa Smp Di Kabupaten Sleman. Jipsindo, 4(1), 1-21. doi:https:// doi.org/10.21831/jipsindo.v4i1.14834 [Indonesian] 